\title{
Alternatif katı atık depolama alanlarının analitik hiyerarşi süreci ve coğrafi bilgi sistemleri ile otomatik olarak belirlenmesi: Sivas ili örneği
}

\author{
Dilara Ciritci ${ }^{1}$ D, Tarık Türk $^{1^{*} \text { (D) }}$ \\ ${ }^{1}$ Sivas Cumhuriyet Üniversitesi, Kampüs, Mühendislik Fakültesi, Harita Mühendisliği Bölümü, Sivas.
}

Öz: Türkiye'de birçok yerleşim biriminde devam eden altyapı projeleri sonucunda kentleşmenin ve kentleşmeye bağll olarak da nüfusun artacağı düşünülmektedir. Bunun sonucunda katı atık miktarındaki artış da kaçınılmaz olacaktır. Bu çalışmada Coğrafi Bilgi Sistemleri (CBS) ve çok ölçütlü karar verme yöntemlerinden biri olan Analitik Hiyerarşi Süreci (AHS) kullanılarak, Sivas Merkez ilçesinde alternatif katı atık depolama alanları, geliştirilen kullanıcı arayüz programı yardımıyla otomatik olarak belirlenmiştir. AHS ile belirlenen ölçütlerin ă̆ırlıkları hesaplanmış ve Sivas ili Merkez ilçesine ait veriler CBS'nin olanak tanıdı̆̆ coğrafi analizler yardımıyla sonuçlar ortaya konmuştur. Elde edilen bu sonuçlar doğrultusunda alternatif katı atık depolama sahaları önerilerek, mevcut katı atık depolama sahasının yerinin uygun olup olmadı̆̆ değerlendirilmiştir.

Anahtar Sözcükler: Analitik hiyerarşi süreci, Coğrafi bilgi sistemi, Düzenli depolama alanı

\section{Automatic determination of alternative landfill sites with analytical hierarchy process and geographical information systems: a case study in Sivas city}

\begin{abstract}
Due to the ongoing infrastructure projects in Turkey, it is estimated that the urbanization and population increase based on urbanization will increase. Therefore, the increase in the amount of solid waste will be inevitable. In this study, alternative landfills in Sivas, Central District, are determined automatically by using Analytic Hierarchy Process (AHP), one of Geographic Information System (GIS) and multi-criteria decision making methods, with a user interface developed. The weights of the criteria were calculated by AHP and the results were represented by the help of geographical analysis enabled by GIS depending on data of Sivas, Central District. In accordance with the results obtained, alternative landfills were proposed and the current location of the landfill was evaluated whether it is suitable or not.
\end{abstract}

Keywords: Analytic hierarchy process, Geographical information system, Landfill site 


\section{Giriş}

Günümüzde toplumların yoğun olarak yaşadığı kentlerde birçok çevresel sorunla karşılaşılmakta olup, ortaya çıkan sorunların çözüm sürecinde karar vericilerin vermiş olduğu yargılarda bilişim teknolojilerinden yoğun olarak yararlanılmaktadır (Güler, 2016). Çevresel bir konu içerisinde yer alan kentsel katı atık yönetimi dünya ülkelerinde üzerinde hassasiyetle durulan bir alandır (Güler, 2016). Literatür incelendiğinde katı atık yönetiminin birçok amacının olduğu görülmektedir. Her ne kadar farklı araştırmacılar tarafından birçok amaç ortaya konsa da, günümüzde yeni amaçların eklenmesi de mümkündür (Balca, 2007). Bu bağlamda katı atık yönetiminin temel amaçları; halk sağlığının iyileştirilmesi ve korunması, çevre kalitesinin korunması, atık miktarının azaltılması ve kaynakların yeniden kazanımının arttırılması, zaman içerisinde değişmekte olan kentsel ihtiyaçları karşılayacak şekilde katı atık sistemlerinin sürekli olarak planlanmasının sağlanması ve bunu yapabilecek kurumsal yapının inşa edilmesi, kentte yaşayan insanlara uluslararası standartta bir hizmet sunulması, mevcut sistemin işletme giderleri için finansman kaynağı ve gelişmiş sistemler için yeni yatırım kaynaklarının sağlanması olarak özetlenmektedir (Balca, 2007).

Atık yönetimi ve alternatif depolama alanlarının tespit edilmesi, karar vericiler ve uygulayıcılar açısından çok fazla zaman alan karmaşık bir süreçtir. Katı atık depolama alanları için uygun yer seçimi çalışmaları; çok yoğun bir coğrafi verinin analiz edilmesini gerektirmektedir. Yer seçimi ölçütleri belirlenirken; genel olarak arazi örtüsü, jeolojik formasyon, idari sınırlar, yüzey suları, karayolu gibi kısıtlayıcı parametreler kullanılmaktadır. Buna karşı̈n ölçütler içerisinde bulunan parametrelerin tamamı çözüm sürecine katılmayabilmektedir. Bu parametrelerin kullanımı çalışma yöntemi ve tecrübelere göre değişiklik gösterebilir. Çalışma bölgesinin seçimine ilişkin mevcut bilgilerin klasik yöntemlerle değerlendirilmesi güç ve uzun süren bir işlemdir (Sadek, El-Fadel \& El-Hougeiri, 2001; Güler, 2016). Buna benzer uygulamalarda bilgi teknolojilerinin kullanımı ile daha hızlı sonuca ulaşılmasının yanı sıra, yöneticilere yardımcı olmak amacıyla veri, belge, bilgi ve iletişim teknolojilerini ve modellerini kullanarak problemleri tanımlamaya ve çözmeye yardımcı araçlar etkili olmaktadır. Coğrafi Bilgi Sistemleri (CBS) verilerin toplanması, depolanması, analiz edilmesi, kullanıcıya sunulması gibi işlevleri bütünleştiren, veriler arası modellemeler oluşturularak ilişki kurulmasını sağlayan önemli bir araçtır. Bu kapsamda CBS, karar vericiler için farklı bir bakış açısı sunması nedeniyle karmaşık problemlerin çözümü için başvurulan önemli bir bilgi sistemidir (Sadek vd., 2001; Lunkapis, Ahmad, Shariff, Mansor \& Mispan, 2004; Nas \& Berktay, 2002; Türk, 2013; Türk, Gümüşay \& Tatar, 2012).

Siddiqui, Everett ve Vieux (1996) Amerika Birleşik Devletleri (ABD)'nin Oklahoma eyaletinde bulunan Cleveland County kentinde CBS ve Analitik Hiyerarşi Süreci (AHS)'ni kullanarak katı atık depolama alanı belirlemek amacıyla bir çalışma gerçekleştirmişlerdir. Kurulacak yeni katı atık depolama alanları için mevcut kuralların ve yerel halkın sunduğu şikayetlerin birtakım zorluklara neden olduğunu vurgulamışlardır. Yapılan çalışmada AHS için mevcut kurallardaki sınırlamalar, bölgelerin nitelikleri, araziye ilişkin değerlendirmeler uzmanlar ve kullanıcılar yardımıyla ortaya konulmuştur. Kao ve Lin (1996) tarafından gerçekleştirilen çalışmada ise katı atık depolama alanında gerekli olan mevcut kurallar, etkenler ve kısıtlamalar hesaba katılarak CBS ile depolanan verilerin amaç doğrultusunda yönetilmesi ile katı atık depolama alanı için yer seçimi gerçekleştirilmiştir. Çalışma alanında hücresel bilgiler kullanılmış olup, çeşitli etkenlerin ağırlıkları ile CBS tabanlı analiz işlemleri yapılmıştır. Lin ve Kao (1999) tarafından yapılan bir başka çalışmada katı atık depolama alanının belirlenmesi için yapılan grid tabanlı modelin düzenlenemeyen mekânsal bilgilerde uygulanamaması üzerine iki değişik model ortaya atılmıştır. Bu modeller arazi değeri ile analizler için gereken eğim ve yol vb. bilgilerin değişimine imkân tanımaktır. Başağaoğlu, Çelenk, Mariulo ve Usul (1997) çalışmalarında Ankara Gölbaşı mahalli idare sınırları içerisinde bulunan kapalı olmayan atık alanının çevreye zarar vermesi nedeniyle, var olan katı atık depolama alanına ilave olarak yeni bir katı atık depolama alanı tespit etmişlerdir. Çalışmada yüzey suları, sulak alanlar, yer altı kaynakları, yollar, topoğrafik eş yükseklik eğrileri ve yerleşim alanları gibi coğrafi veriler dikkate alınarak birçok alternatif alan belirlenmiştir. Baban ve 
Flannagan (1998)'ın yaptığı çalışma ile CBS tabanlı katı atık depolama yerlerini tespit etmeyi amaçlamışlardır. Bu çalışmada, Birleşik Krallık’ta uygulanan kurallar, diğer devletlerin belirlediği sınırlamalar ve Avrupa Birliği talimatları araştırılarak basite indirgenmiş ve belirlenen ölçütlerin faydaları vurgulanarak CBS ile depolama alanları tespit edilmiştir.

Şener Ş., Şener E., Nas ve Karagüzel (2010)'in yaptı̆̆ı çalışmada depolama alanının yerini belirlemek zor bir süreç olduğundan toplumsal, çevresel ve yöntemsel değişkenlerin göz ardı edilmemesi gerektiği vurgulanmıştır. Çalışma alanı olarak Konya il sınırı içerisindeki Beyşehir Gölü havzası seçilmiştir. Jeoloji, arazi kullanımı, eğim ve yol gibi farklı verilerden yararlanılarak AHS ve CBS ile çalışma gerçekleştirilmiştir. Yıldırım (2012) yaptığı çalışmada Mersin ilinde CBS ve AHS'den yararlanarak en uygun katı atık depolama sahası belirlenmiştir. Çalışma alanında eğim, bakı, yükseklik, yüzey suları ve yerleşim alanları vb. gibi 11 farklı veriden faydalanılmıştır. Yapılan analizlerle beş farklı alternatif katı atık depolama bölgesi tespit edilmiştir. Yal ve Akgün (2014) yaptıkları çalışma ile Ankara ilinin Gölbaşı belediyesi sınırlarını kapsayan alanda CBS ve Çok Ölçütlü Karar Verme (ÇÖKV) yöntemlerini kullanarak alternatif katı atık depolama alanlarını belirlemeye çalışmışlardır. Çalışma alanında jeoloji, eğim, yerleşim, tarım ve erozyon gibi girdi verileri kullanılmıştır.

Aksoy ve San (2016)'ın yaptığı çalışmada depolama alanı için yer seçiminin çok önemli olduğu ve şehrin geleceğini etkilediği düşüncesi savunulmuş ve mevcut depolama sahasının yakın gelecekte yeterli olmayacağına vurgu yapılmıştır. Antalya için; jeoloji, fay hatları, heyelanlar, nehir, göl, yükseklik, eğim, nüfus, yol ve sıcaklık gibi veriler ile CBS tabanlı AHS yöntemi kullanılarak yeni depolama alanları belirlenmiştir. Yine Aksoy ve San (2019) tarafından yapılan benzer çalışmada 35 yıllık nüfus tahmini dikkate alınıp sayısal yükseklik modeli, eğim, sıcaklık, yağış, deprem bölgeleri, yola uzaklık, jeoloji ve fay hattına olan uzaklık gibi veriler kullanılarak CBS tabanlı AHS yöntemiyle atık depolama için alternatif alanlar belirlenmiştir.

Gerçekleştirilen bu çalışmalarda birçok parametre dikkate alınsa da, son dönemde çevre ile ilgili sorunların çözülmesi önem kazanmış ve bu sorunlar karşısında doğru bir şekilde sonuç çıkarabilmek adına çok fazla uğraş ortaya konulmuştur. Maddi odaklı fikirler yerine ÇÖKV yöntemlerini içeren çeşitli çalışmalar yapılmıştır (Hokkanen \& Salminen, 1997). Gelişmekte olan ülkelerde nüfusun ve dolayısıyla insan kaynaklı etkinliklerin artması sonucu şehirleşme hızlanmıştır (Sumathi, Natesan \& Sarkar, 2008). Nüfusun artması, tüketim şeklinin farklılaşması, üretilen mal ve hizmet kapasitesinde meydana gelen artış, kazancın değişmesi, şehirleşme ve sanayileşmenin sonucu olarak katı atık üretimi ve çeşitliliği artmıştır (Ngoc \& Schnitzer, 2009).

2018'deki Adrese Dayalı Nüfus Kayıt Sistemi Sonuçları (ADNKS)'na göre Türkiye'nin nüfusu 82003882 'dir. Yoğun nüfusla birlikte çevre ile etkileşimin artması sonucunda katı atık yönetimi önemli bir konu haline gelmiştir. Katı atık yönetimi ve yok etme yöntemleri, yöneticiler ve konuyla ilgili tarafları kapsayan uzun bir süreci ifade etmektedir. Atık yönetiminde dikkat edilmesi gereken hususlar içerisinde, depolama alanı için en uygun yer seçiminin yanı sıra birçok faktörün de dikkate alınması gelmektedir. Ancak temel sorun seçim için evrensel bir formülasyonun bulunmamasıdır (Vasiljević, Srdjević, Bajčetić \& Miloradov, 2012).

Bu değerlendirmeler ışığında gerçekleştirilen bu çalışmada, CBS'nin imkân tanıdığı coğrafi analizler ve AHS ile elde edilen ölçüt ağırlıkları kullanılarak, Sivas İli Merkez İlçesinde alternatif katı atık depolama alanlarının geliştirilecek kullanıcı arayüz programı ile otomatik olarak elde edilmesi amaçlanmaktadır. Literatür incelendiğinde konuyla ilgili çok sayıda çalışma olduğu görülmektedir. Bu çalışmanın literatürdeki diğer benzer çalışmalardan en önemli farkı katı atık depolama alanlarının gerekli parametreler girildikten sonra otomatik olarak elde edilmesidir. Literatürdeki çalışmalardan biri de çalışmamızla bazı benzer özellikler taşıyan Güler (2016) tarafından yapılan çalışmadır. Bu çalışmada, Güler'in (2016) yapmış olduğu İstanbul ilinde AHS ve CBS ile alternatif katı atık düzenli depolama alanlarının kolaylıkla belirlenmesine yönelik çalışmadan farklı olarak; yeryüzü şekillerine göre karar verilmek suretiyle derecelendirme yapılmış ve daha önce karar verilen ölçüt aralıklarına 
göre yeniden sınıflandırma işlemi ile oluşturulan veriler ağırlıklı toplama yöntemiyle çakıştırılmış, elde edilen ağırlıklar oluşturulan modelde değişken olarak tanımlanmıştır. Her bir faktöre ait ağırlık değerleri daha önce AHS ile hesaplanan değerler dikkate alınarak en uygun yer seçimi analizi gerçekleştirilmiştir. Bir diğer fark da kısıtlayıcı alanların çalışmamızda ilk aşamada, Güler (2016) tarafından yapılan çalışmada en son aşamada maskelenmesidir. Sonuç olarak, çalışmamız kapsamında geliştirilen kullanıcı arayüz programına sadece Sayısal Arazi Modeli (SAM), yerleşim, jeoloji, arazi kullanımı ve kısıtlayıcı faktör verileri girilmiş ve belirtilen tüm işlemler tam otomatik olarak gerçekleştirilmiştir.

\section{2. Çalışma Alanı}

Çalışma alanı olarak Sivas Merkez İlçesini kapsayan bir bölge seçilmiştir (Şekil 1). Sivas İç Anadolu'nun doğusunda yer alan, Anadolu'daki tarihi İpek Yolu güzergâhlarının kesiştiği bir yerde konumlanmış ve ünlü Kral Yolu’nun da geçtiği büyük bir ildir. Sivas'ın genel nüfusu 2018 yılı sonu itibariyle 646 608, Sivas il merkezi nüfusu (belde ve köyler dahil) ise 377 561'dir. Sivas, 16 ilçesi (Merkez hariç) ve 1245 köyü ile önemli bir idari yapıya sahiptir. Denizden ortalama yüksekliği 1000 metrenin üzerindedir. Karasal iklimin hakim olduğu Sivas’ta, yaz mevsimi çok sıcak ve kurak geçmekte olup oldukça kısadır. Kış ayları ise soğuk, uzun ve kar yağışlıdır. İklim ve yer şekilleri özellikleri bakımından Sivas doğal bir orman alanı olması gerekirken; yüzyıllar boyunca devam eden ormanların tahribatı yüzünden bugün Sivas çevresinde orman alanları fazla geniş bir yer tutmamaktadır. Sivas'ın asıl önemli bitki örtüsü bozkırdır.

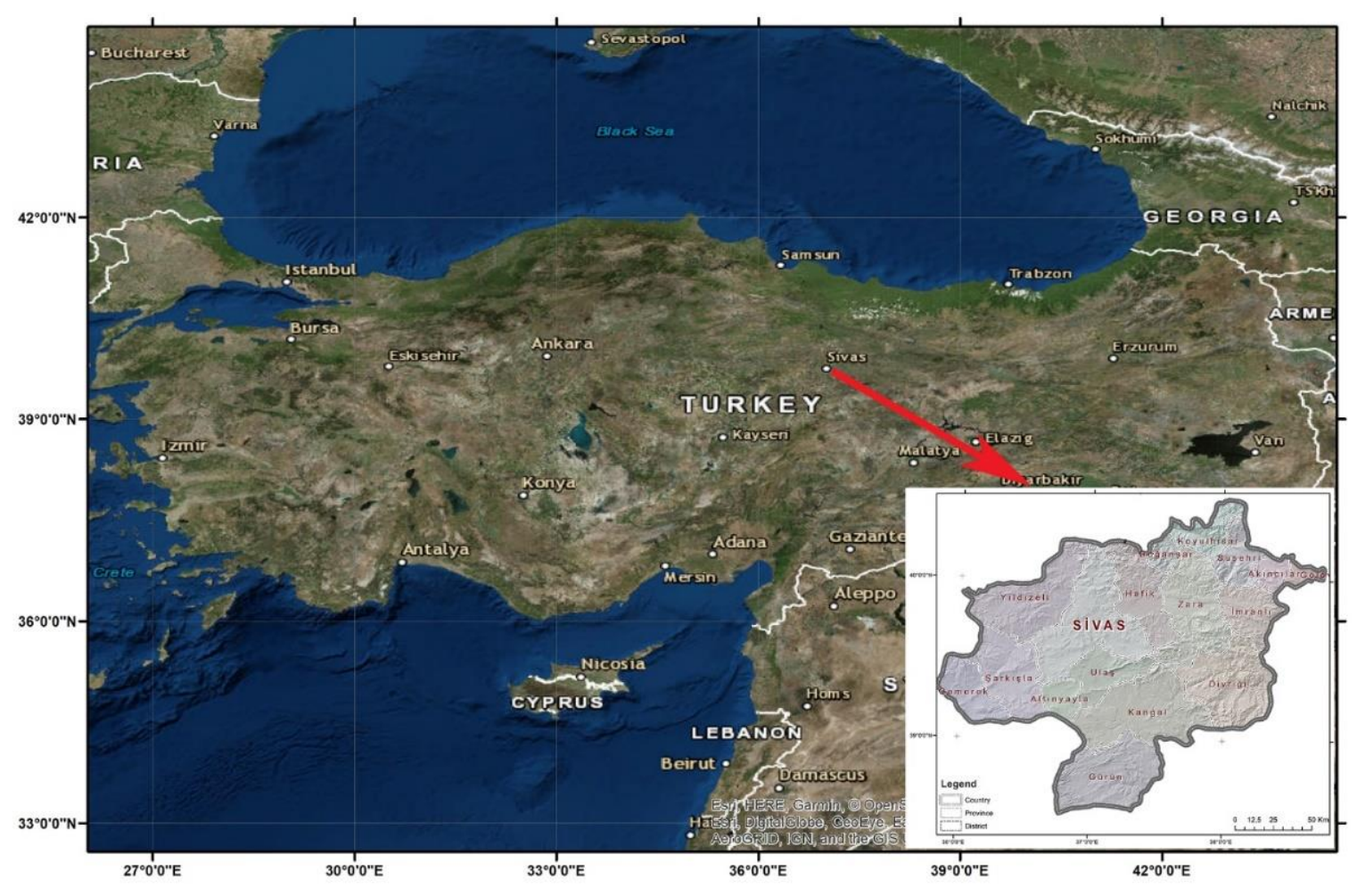

Şekil 1: Çalışma alanı

\section{Yöntem}

Bu çalışmanın amacı CBS ve AHS kullanılarak, Sivas Merkez ilçesinde alternatif katı atık depolama alanlarının, geliştirilen kullanıcı arayüz programı yardımıyla otomatik olarak belirlenmesidir. Bu amaç doğrultusunda önerilen yöntem, kullanılan veriler ve işlem adımları Şekil 2'de gösterilmektedir. 


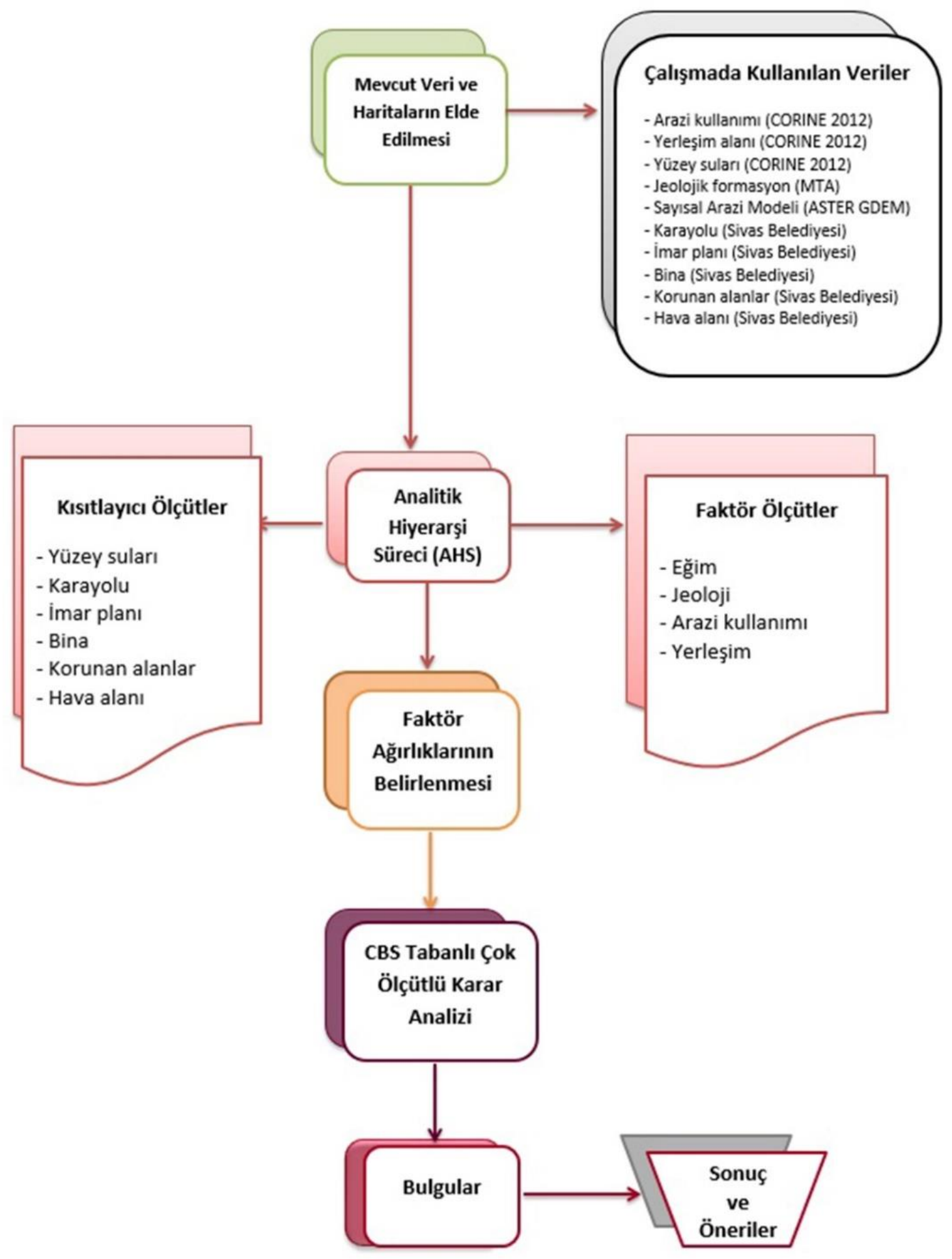

Şekil 2: Çalışma kapsamında kullanılan veriler ve izlenen adımlar

Çalışma kapsamındaki analizler ArcGIS 10.1 CBS yazılımında gerçekleştirilmiştir. Elde edilen coğrafi veriler için World Geodetic System (WGS) 1984 Datumu ve Universal Transverse Mercator (UTM) projeksiyonu Zone 37N koordinat sistemi kullanılmıştır.

Çalışma için belirlenmiş olan kısıtlayıcı ölçütlere ait verilerde (karayolu, bina, imar planı vb.) uygun olmayan alanlar "0", uygun alanlar "1" olarak temsil edilmektedir. Faktörlere ait veriler (eğim, yerleşim, jeoloji, arazi kullanımı) önce derecelendirilmiş, daha sonra hesaplanan ağırlıklarla çarpılarak son ağırlıkları hesaplanmıştır. Uygunluk haritası oluşturulurken ise elde edilen kısıtlayıcı haritalar ile ağırlıklandırılan faktör haritaları çarpılarak uygun alanlar içerisinde 
mevcut depolama alanlarının bulunup bulunmadığı araştırılmış ve alternatif alanlar tespit edilmeye çalışılmıştır.

\subsection{Katı Atık Depolama Tesisi Yer Seçiminde Etkili Olan Faktörler}

Çalışmada alternatif sahaların belirlenmesinde, ülkemizde kullanılan Atık Yönetimi Yönetmeliği'nde (Atık Yönetimi Yönetmeliği, 2015) ortaya konulmuş olan kısıtlamalar dikkate alınarak, literatürde sıklıkla tercih edilen faktörler göz önünde bulundurulmuştur. Yer seçimi ölçütleri belirlenirken; genel olarak arazi örtüsü, jeolojik formasyon, idari sınırlar, yüzey suları, karayolu gibi veriler kullanılmaktadır. Ancak, bu ölçütler içerisinde bulunan parametrelerin tamamı problemin çözüm sürecine katılmayabilir. Kullanılan parametreler çalışma yöntemi ve tecrübelere göre değişiklik gösterebilir.

Literatürde yapılan çalışmalara bakıldığında; Başağaoğlu vd. (1997) Ankara Gölbaşı'nda yaptığı çalışmada yüzey suları, sulak alanlar, yer altı kaynakları, yollar, topoğrafik eş yükseklik eğrileri ve yerleşim alanları gibi coğrafi verileri dikkate almıştır. Şener vd. (2010) Konya il sınırı içerisinde depolama alanının yerini belirlemek için gerçekleştirdikleri çalışmada jeoloji, arazi kullanımı, eğim ve yol gibi farklı verilerden faydalanmışlardır. Yıldırım (2012) Mersin'de yaptığı çalışmada ise eğim, bakı, yükseklik, yüzey suları ve yerleşim alanları gibi verileri kullanmıştır.

$\mathrm{Bu}$ çalışma kapsamında ise çevresel ve ekonomik olmak üzere iki farklı kategoriye ait toplam 11 adet etki faktörü belirlenerek kullanılmıştır. Çevresel faktörler; arazi kullanımı, jeoloji, yerleşim alanları, yüzey suları (göl, baraj), havaalanı, bina, imar planı ve korunan alanlardır. Ekonomik faktörler ise eğim ve karayollarıdır. Faktörlere ait alt ölçütler derecelendirilmiş ve AHS ile hesaplanan ağırlıklarla çarpılarak bütün ölçütlerin çalışmada kullanılan son ağırlıkları hesaplanmıştır.

\subsection{1 Ĕgim}

Ekonomik faktörlerden biri olan eğim için ASTER GDEM (Global Digital Elevation Model) SAM kullanılmıştır. Eğimin arttığı bölgelerde inşaat maliyeti artacağından ekonomik faktör kategorisinde yer almıştır. Eğimin \%20'nin üstünde olduğu alanlar katı atık depolama sahası için uygun olmayan alan olarak belirlenmiştir. Eğim faktörü için belirlenen alt ölçütler yeniden sınıflandırma işlemine tabi tutularak eğim faktör haritası hazırlanmıştır (Tablo 1 ve Şekil 3).

\subsubsection{Jeoloji}

Çevresel faktörlerden biri olan jeoloji için belirlenen alt ölçütler volkanik özellikte olan bölgelerin sınırlı su geçirme özelliğine sahip olmalarından dolayı depolama sahası yer seçiminde uygun olabilecek alanlar olarak belirlenmiştir. Metamorfik ve sedimanter kayaçlar özelliklerine göre daha az su geçirgenliğine sahip oldukları için konunun uzmanı kişilerle de görüşülerek değer olarak yüksek atama yapılmıştır. Jeoloji faktörü için belirlenen alt ölçütler yeniden sınıflandırılarak jeoloji faktör haritası hazırlanmıştır (Tablo 1 ve Şekil 3).

\subsubsection{Arazi Kullanımı}

Çalışmada kullanılan çevresel faktörlerden biri de arazi kullanımıdır. CORINE verisinden belirlenen alt ölçütler yeni bir katman olarak çıkarılmıştır. Sulu ve sulu olmayan tarım için kullanılan bölgeler ve ormanlık alanlar atık depolanması için uygun değildir. Bu nedenle, çalılık bölgeler, mera bölgeleri ve kayalık alanlar yer seçimi için daha uygun alan olarak değerlendirilerek yüksek değerler atanmıştır. Belirlenen arazi kullanımı ölçüt değerlerine yeniden sınıflandırma işlemi yapılarak arazi kullanım faktör haritası üretilmiştir (Tablo 1 ve Şekil 3). 


\subsubsection{Yerleşim}

Katı atık depolama alanlarının belirlenmesinde Atık Yönetimi Yönetmeliği göz önünde bulundurulmuş ve şehir planlama konusunda uzman kişilerden görüş alınarak yerleşim alanlarına en az bir kilometre (km) uzaklıkta yer almasına karar verilmiştir. Ayrıca çevrede oluşturacağı zararlı etkiler dikkate alınarak yerleşim alanlarına uzaklık arttıkça maliyet de artacağından alt ölçütlere düşük değerler atanmıştır (Tablo 1 ve Şekil 3).

Tablo 1: Parametrelere ait ölçüt değerleri

\begin{tabular}{|c|c|c|}
\hline Parametre Adı & Değer & Yeni değer \\
\hline \multirow{9}{*}{ Eğim (\%) } & $0-3$ & 5 \\
\hline & $3-7$ & 4 \\
\hline & $7-10$ & 3 \\
\hline & $10-13$ & 2 \\
\hline & $13-17$ & 2 \\
\hline & $17-21$ & 1 \\
\hline & $21-26$ & 0 \\
\hline & $26-32$ & 0 \\
\hline & $32-50$ & 0 \\
\hline \multirow{13}{*}{ Jeoloji } & Kireçtaş1 & 1 \\
\hline & Karbonatlar ve Yer Kırıntılar & 0 \\
\hline & Mermer & 0 \\
\hline & Ayrılmamış Karasal Kırıntılar & 0 \\
\hline & Granit & 0 \\
\hline & Granitoyidler & 5 \\
\hline & Ayrılmamış Bazik ve Ultra bazik Kayalar & 0 \\
\hline & Kirıntılar ve Karbonatlar & 2 \\
\hline & Karasal Karbonat & 0 \\
\hline & Ayrılmamış Karasal Kırıntılar & 0 \\
\hline & Andezit & 0 \\
\hline & Proklastik Kayalar & 0 \\
\hline & Ayrılmamıș Volkanitler & 3 \\
\hline \multirow{5}{*}{ Arazi Kullanımı } & Sulu tarım & 0 \\
\hline & Kuru tarım & 1 \\
\hline & Orman & 2 \\
\hline & Mera & 3 \\
\hline & Çıplak Kaya & 5 \\
\hline \multirow{4}{*}{ Yerleşim $(\mathrm{km})$} & $0-1$ & 5 \\
\hline & $1-5$ & 2 \\
\hline & 5- 578 & 0 \\
\hline & $578-976$ & 0 \\
\hline
\end{tabular}

\subsection{Faktör Ağırıklarının AHS ile Belirlenmesi}

Çalışma alanı için AHS ile çevresel ve ekonomik faktörler tanımlanmıştır (Şekil 4). Çevresel ve ekonomik faktörlere ait alt ölçütler tespit edilerek standart bir değerlendirme olması istendiğinden 0 ile 5 arasında değerler verilmiştir. AHS için karar matrisleri hesaplanmıştır. Kaynaklardan yararlanılarak karar matrisindeki faktörler önem sırasına göre elde edilmiştir. 

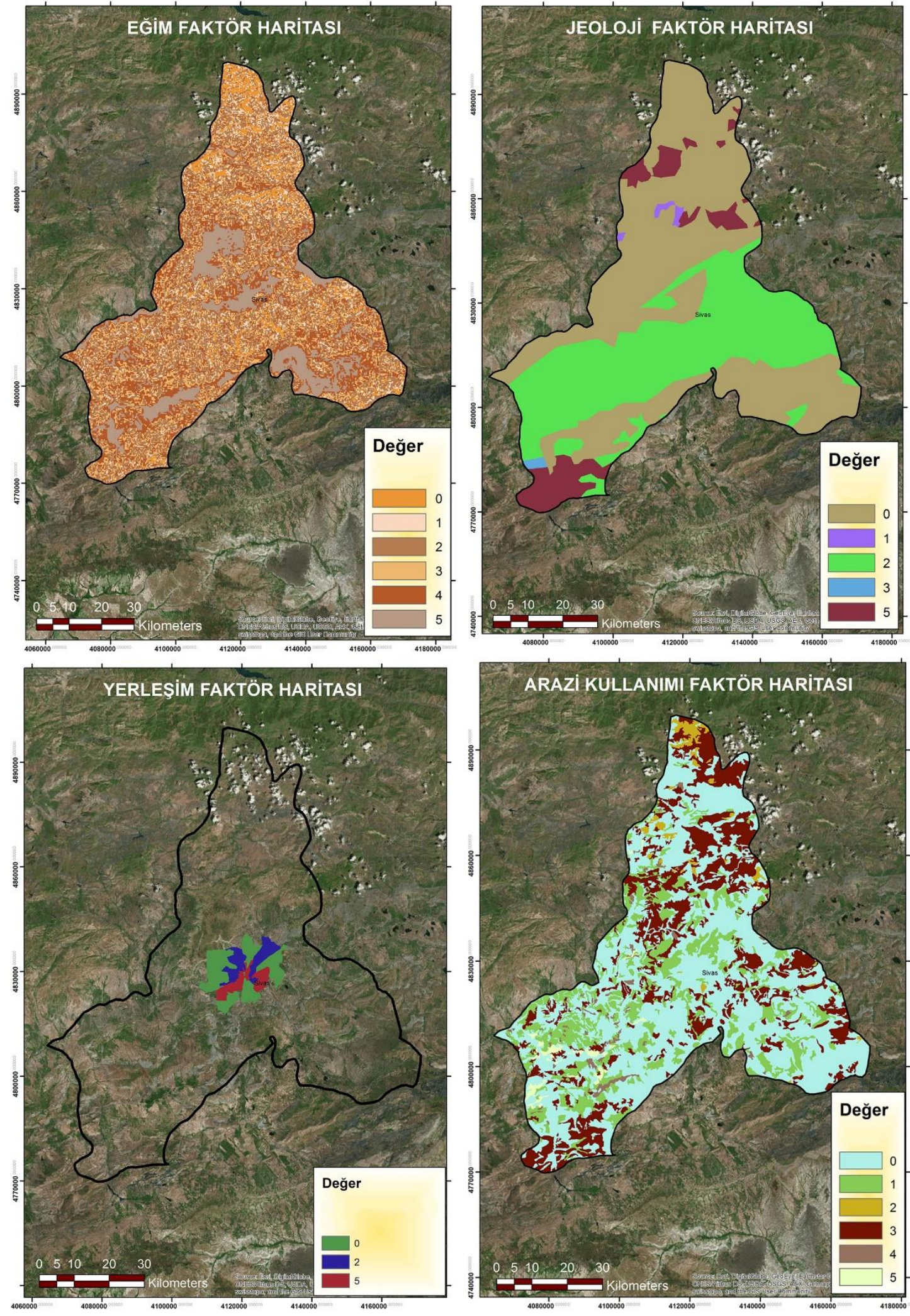

Şekil 3: Yeniden sınıflandırılmış parametre haritası 


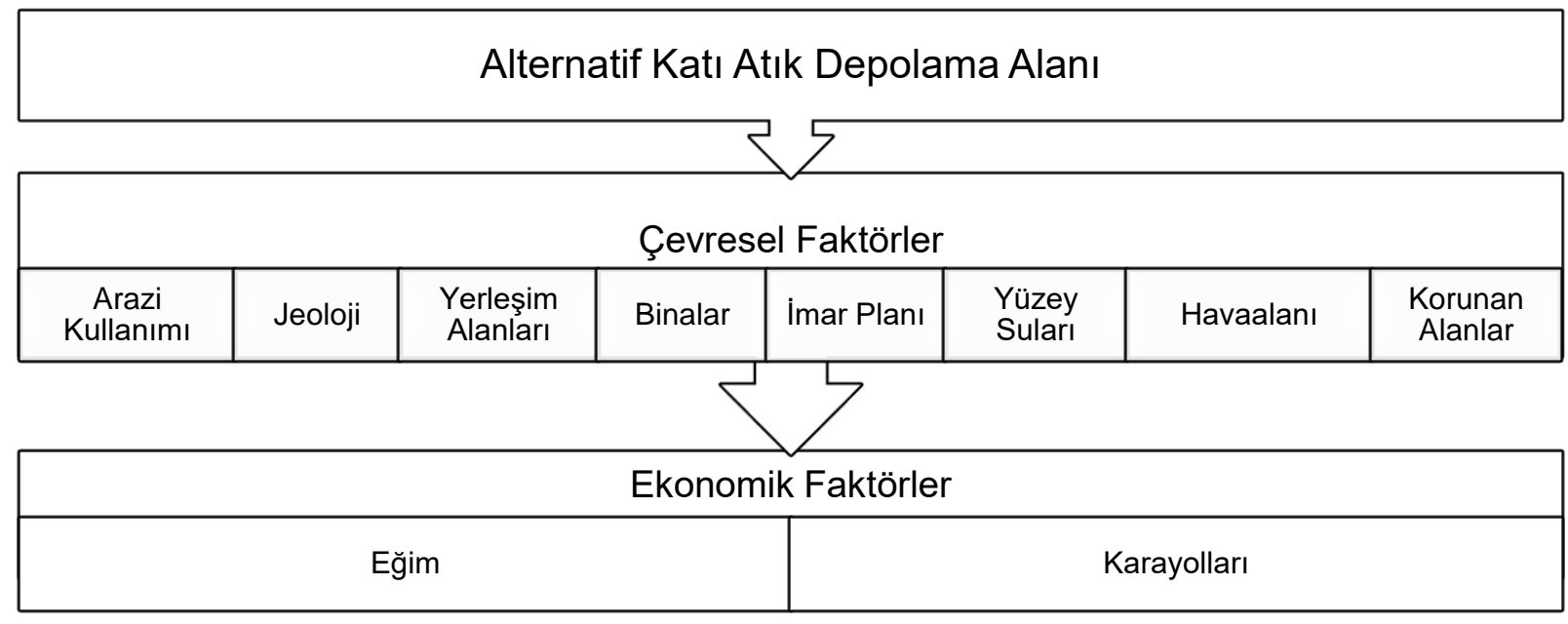

Şekil 4: Uygun depolama alanı hiyerarşi modeli

Faktör bileşenlerine ait ölçüt değerlerinin standartlaştırılması ve üretilen haritalardaki değerlerinin yeniden atanmasının ardından, faktör ağırlıkları belirlenmiştir (Tablo 2).

Tablo 2: Faktör ağırlıkları

\begin{tabular}{lccccc}
\hline & & F1 & F2 & F3 & F4 \\
\hline Arazi kullanımı & F1 & 1.00 & 2.00 & 3.00 & 5.00 \\
\hline Jeoloji & F2 & 0.50 & 1.00 & 2.00 & 3.00 \\
\hline Yerleşim & F3 & 0.33 & 0.50 & 1.00 & 5.00 \\
\hline Eğim & F4 & 0.20 & 0.33 & 0.20 & 1.00 \\
\hline \multicolumn{2}{c}{ Süitun toplamı } & 2.03 & 3.83 & 6.20 & 14.00 \\
\hline \multicolumn{1}{c}{$\lambda \max$} & & & & \\
\hline
\end{tabular}

Karşılaştırma matrisleri sonucunda CI (Consistency Index) değerinin teoremlerde istenilen değer olan 0.10'un altında elde edilmesi ile hesaplanan ağırlıklar çalışmada kullanılmıştır (Akgün vd., 2014). Elde edilen bu veriler doğrultusunda kısıtlayıcı haritalar hazırlanmıştır (Şekil 5).

\subsection{Depolama Sahası Yer Seçimi İçin Kullanıcı Arayüz Programı Geliştirilmesi}

Katı atık depolama alanı yer seçiminde kullanılan faktörler ve ağırlıklar çalışılan bölgeye ve tercihlerdeki önem sırasına göre farkl1lık gösterebilmektedir. Ekonomik, çevresel veya toplumsal içerikli senaryolar ortaya konulabilmektedir. Değişebilen dinamik bir model tasarlanmasıyla birlikte işlemlerin uygulanması kolaylıkla gerçekleşecek ve verilerin işlenmesi sırasında oluşabilecek hatalar en aza indirilecektir (Güler, 2016).

Yapılan çalışmayla birlikte katı atık depolama alanı yer seçiminde ArcGIS 10.1 yazılımı ortamında "model builder" ile kullanıcı arayüz programı geliştirilmiştir. Konu ile ilgili herhangi bir yönetmelik değişikliğinde getirilen sınırlandırmaların farklılaşması halinde bu arayüz programı içerisinde gerekli parametreler düzenlenerek güncel sonuçlara çok kısa sürede ulaşılabilecektir. Ölçütlerin ağırlıklarına farklı bir değer atanması gerektiğinde geliştirilen kullanıcı arayüz programı yardımıyla kolaylıkla gerçekleştirilebilecektir. Geliştirilen bu arayüz programı çalışmada kullanılan verilere göre hazırlanmış olup farklı çalışma alanlarında aynı parametreler kullanılarak yer seçimi işlemi gerçekleştirilebilecektir. Önceden kararlaştırılan ölçüt aralıkları dikkate alınarak yeniden sınıflandırma işlemine girdi olacak şekilde bağlantı kurulmuştur. Yeniden sınıflandırma işleminin yapılması sonucu oluşan veriler ağırlıklı toplama yöntemiyle çakıştırılmıştır. Her bir faktöre 
ait ağırlık değerleri daha önce AHS ile hesaplanan değerler dikkate alınarak en uygun yer seçimi analizi gerçekleştirilmektedir (Şekil 6). Sonuç olarak, geliştirilen kullanıcı arayüz programına sadece SAM, yerleşim, jeoloji, arazi kullanımı ve kısıtlayıcı faktör verileri girilmekte ve belirtilen tüm işlemler tam otomatik olarak gerçekleştirilmektedir.
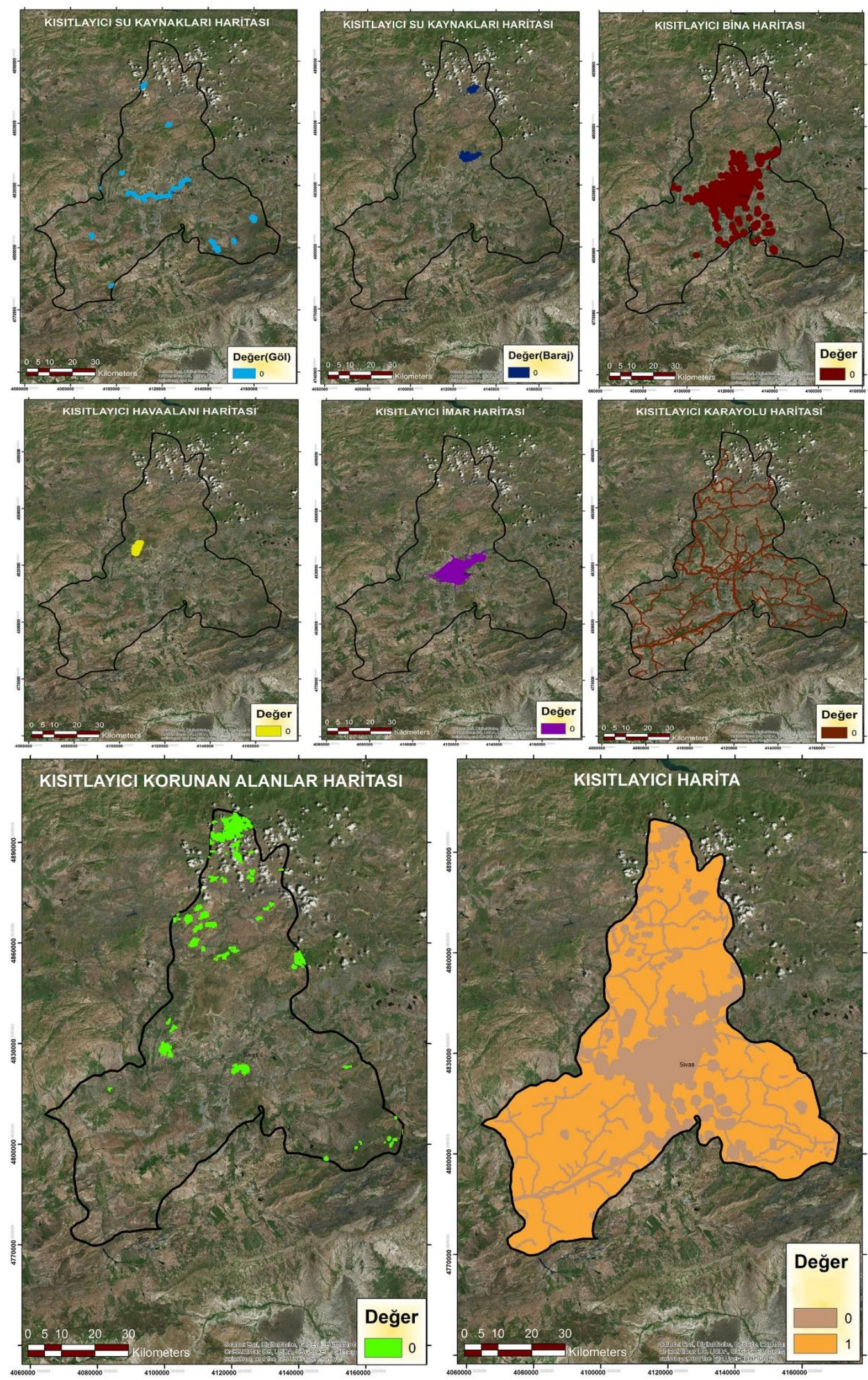

Şekil 5: Kısıtlayıcı haritalar ve tüm kısıtlayıcı harita 


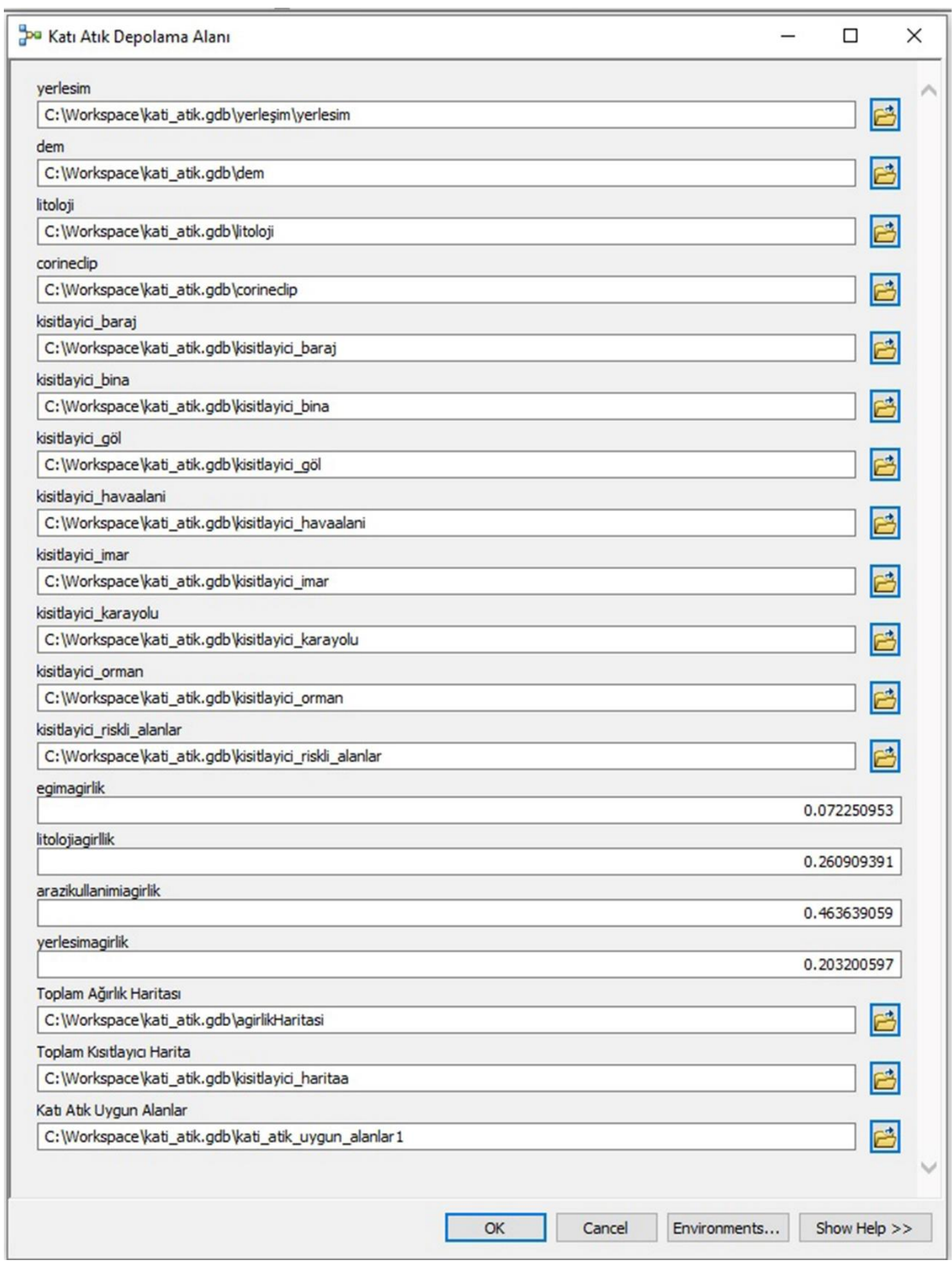

Şekil 6: Geliştirilen kullanıcı arayüz programı

\section{Bulgular ve Tartışma}

Çalışmada, literatür incelemesi ile sahanın özgün özellikleri dikkate alınarak belirli ölçütler yüksek olacak şekilde ağırlık puanları verilerek katmanlar yeniden sınıflandırılmıştır. Ağırlıklandırmada; yerleşime uzaklık, akarsulara uzaklık, eğim durumu, arazi kullanımı, yollar, havaalanı ve imar planı gibi özellikler dikkate alınmıştır. CBS’nin olanak sağladığı mekânsal analizler ile sonuç ürün elde edilmiştir. Geliştirilen kullanıcı arayüz programının çalıştırılması ile katı atık düzenli depolama sahası için alternatif alanlar otomatik olarak belirlenmiştir. Analizler yapılarak tespit edilen bölgeler; uygun değil ve uygun 
olmak üzere iki sınıfa ayrılmıştır (Şekil 7).

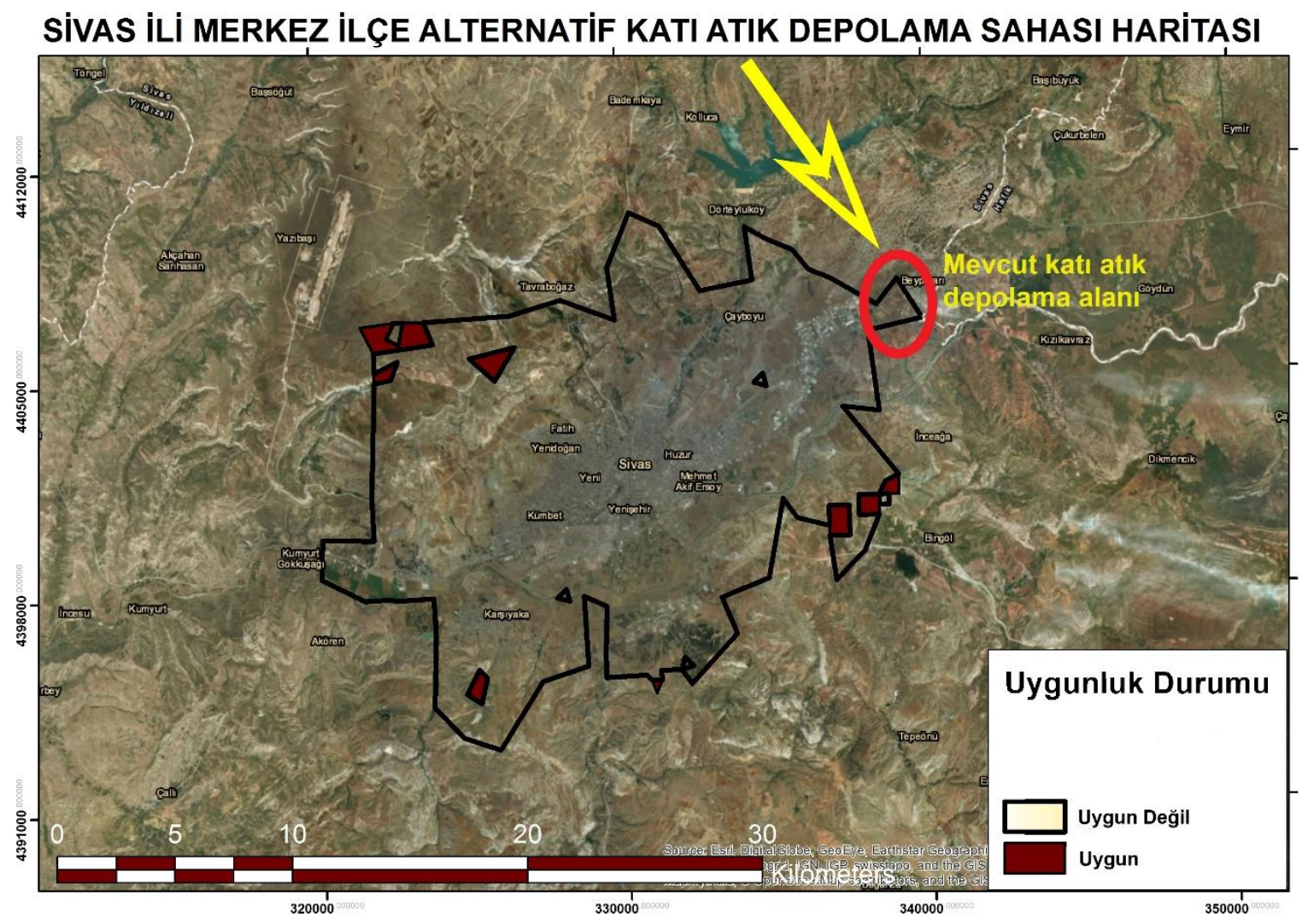

Şekil 7: Sivas ili Merkez ilçe katı atık depolama sahası uygunluk haritası

Elde edilen uygun alanlar içerisinde mevcut depolama alanlarının bulunup bulunmadığı da araştırılmıştır. Seyfebeli Çöp Depolama Merkezi çalışmada imar sahasıyla örtüşmektedir. Bu nedenle çalışmada uygun olmayan alan olarak sınıflandırılan bölge içinde yer almaktadır (Şekil 7). Alternatif depolama alanları ise daha çok kent yerleşiminin kuzey batı ve güney doğu kısımlarında kümelenmektedir. Uygun olarak belirlenen kuzey batıdaki alternatif depolama alanları, Sivas Nuri Demirağ Havalimanı'na ve yeni kurulan Sivas Bilim ve Teknoloji Üniversitesi Yerleşkesi’ne yakın bir mesafededir. Bu nedenle, Sivas merkez için kentin güney doğusunda tespit edilen alanlar en uygun depolama alanları olarak önerilebilir.

\section{Sonuç ve Öneriler}

Bu çalışmada Sivas ili Merkez ilçe sınırı içerisinde bulunan en uygun katı atık depolama alanlarının konumu otomatik olarak tespit edilmiştir. Bu süreçte toplam 11 farklı ölçüt dikkate alınarak CBS’nin olanak sağladığı coğrafi analizler ve ÇÖKV Yöntemlerinden AHS kullanılarak var olan birçok fiziksel, çevresel, sosyal ve ekonomik faktörler dikkate alınmış ve veride çeşitlilik sağlanarak etkili ve uygulanabilir sonuçlar üretebileceği sonucu ortaya çıkarılmıştır. Depolama sahası yer seçiminde etkili olan faktörler yasal düzenlemeler, çalışma bölgesinin özellikleri ve kaynak araştırmasıyla tespit edilmiştir. Bu kapsamda çalışmada kullanılan yöntemin karar vericiler için yardımcı bir araç olabileceği düşünülmektedir.

Bu çalışmanın literatürdeki diğer benzer çalışmalardan en önemli farkı, geliştirilen kullanıcı arayüz programı ile analizlerin daha hızlı ve etkin bir şekilde yapılarak sonuca ulaşılmasıdır. İhtiyaç duyulan girdi veriler kullanılarak gerekli tüm coğrafi analiz ve sorgulama işlemleri otomatik olarak gerçekleştirilmekte ve depolama sahası için uygun olma durumlarına göre sınıflandırılarak sonuç haritası üretilmektedir. Bu arayüz programı aynı parametreler dikkate alınarak farklı bir çalışma alanı 
için de uygulanabilecek olup, esnek bir yapıya sahip olarak geliştirilmiştir. Gerekli parametrelerin ya da ağırlıkların ilgili mevzuat kapsamına göre değişiklik göstermesi durumunda, kullanıcı arayüz programına müdahale edilerek çok kolay bir şekilde yeniden uyarlanabilmektedir.

Diğer taraftan Sivas il merkezindeki mevcut Seyfebeli Çöp Depolama Merkezi, bu çalışma kapsamında imar sahası içerisinde yer aldığından uygun olmayan alan içerisinde yer almaktadır. Bu çalışma ile tespit edilen alternatif katı atık depolama alanlarının her geçen gün nüfusu ve katı atık miktarı artan Sivas ili için yardımcı olabileceği ve karar vericiler için etkin çözüm sağlayabileceği değerlendirilmektedir.

\section{Kaynaklar}

Akgün, A.A., Alkay, E., Kerimoğlu, E., Koramaz, T.K., Kundak, S., Okumuş, G. \& Özçevik, Ö. (2014). Şehir Planlamada Analiz ve Değerlendirme Teknikleri (s. 132-147). Literatür Yayınc1lı.

Aksoy, E., \& San, B. T. (2016). Using MCDA and GIS for landfill site selection: central districts of Antalya province. International Archives of the Photogrammetry, Remote Sensing \& Spatial Information Sciences, 41.

Aksoy, E., \& San, B. T. (2019). Geographical information systems (GIS) and multi-criteria decision analysis (MCDA) integration for sustainable landfill site selection considering dynamic data source. Bulletin of Engineering Geology and the Environment, 78(2), 779791.

Atık Yönetimi Yönetmeliği. (2015, 04 Şubat). Resmi Gazete (Sayı: 29314). Erişim adresi: http://www.resmigazete.gov.tr/eskiler/2015/ 04/20150402-2.htm

Başağaoğlu, H., Çelenk, E., Mariulo, M. A., \& Usul, N. (1997). Selection of waste disposal sites using GIS 1. JAWRA Journal of the American Water Resources Association, 33(2), 455-464.

Baban, S. M., \& Flannagan, J. (1998). Developing and implementing GIS-assisted constraints criteria for planning landfill sites in the UK. Planning Practice \& Research, 13(2), 139-151.

Balca, Y. (2007). Düzenli depolama alanı belirlemede karar destek sistemi kullanımı (Doktora Tezi). İstanbul Teknik Üniversitesi Fen Bilimleri Enstitüsü Fen Bilimleri Enstitüsü, İstanbul, Türkiye.

Güler, D. (2016). Analitik Hiyerarşi Yöntemi Ve Coğrafi Bilgi Sistemleri İle Alternatif Katı Atık Düzenli depolama Alanı Yer Seçimi: İstanbul İli Örneği (Doktora Tezi). İstanbul Teknik Üniversitesi Fen Bilimleri Enstitüsü, İstanbul, Türkiye.

Hokkanen, J., \& Salminen, P. (1997). Choosing a solid waste management system using multicriteria decision analysis. European journal of operational research, 98(1), 19-36.

Kao, J. J., \& Lin, H. Y. (1996). Multifactor spatial analysis for landfill siting. Journal of environmental Engineering, 122(10), 902-908.

Lin, H. Y., \& Kao, J. J. (1999). Enhanced spatial model for landfill siting analysis. Journal of environmental engineering, 125(9), 845-851.

Lunkapis, G. J., Ahmad, N., Shariff, A. R. M., Mansor, S., \& Mispan, R. M. (2004). GIS as decision support tool for landfills siting. In Map Asia Conference.

Nas, B., \& Berktay, A. (2002). Çevre problemlerinin çözümünde coğrafi bilgi sistemlerinin kullanımı. Coğrafi Bilgi Sistemleri Bilişim Günleri. İstanbul, Türkiye, 30-31.

Ngoc, U. N., \& Schnitzer, H. (2009). Sustainable solutions for solid waste management in Southeast Asian countries. Waste management, 29(6), 1982-1995.

Sadek S., El-Fadel M. \& El-Hougeiri N. (2001). Optimizing Landfill Siting Through GIS Application, Seventeenth International Conference on Solid Waste Technology and Management, Philadelphia.

Siddiqui, M. Z., Everett, J. W., \& Vieux, B. E. (1996). Landfill siting using geographic information systems: a demonstration. Journal of environmental engineering, 122(6), 515-523.

Sumathi, V. R., Natesan, U., \& Sarkar, C. (2008). GIS-based approach for optimized siting of municipal solid waste landfill. Waste management, 28(11), 2146-2160.

Şener, Ş., Şener, E., Nas, B., \& Karagüzel, R. (2010). Combining AHP with GIS for landfill site selection: a case study in the Lake Beyşehir catchment area (Konya, Turkey). Waste management, 30(11), 2037-2046. 
Türk, T., Gümüşay, Ü., \& Tatar, O. (2012). Creating infrastructure for seismic microzonation by Geographical Information Systems (GIS): A case study in the North Anatolian Fault Zone (NAFZ). Computers \& geosciences, 43, 167-176.

Türk, T. (2013). Investigating environmental health studies using geographical information systems: cancer case study. Polish Journal of Environmental Studies, 22(5), 1505-17.

Vasiljević, T. Z., Srdjević, Z., Bajčetić, R., \& Miloradov, M. V. (2012). GIS and the analytic hierarchy process for regional landfill site selection in transitional countries: a case study from Serbia. Environmental management, 49(2), 445-458.

Yal, G. P., \& Akgün, H. (2014). Landfill site selection utilizing TOPSIS methodology and clay liner geotechnical characterization: a case study for Ankara, Turkey. Bulletin of Engineering Geology and the Environment, 73(2), 369-388.

Yıldırım, Ü. (2012). Mersin ili için alternatif katı atık depolama alanlarının analitik hiyerarşi prosesi ve coğrafi bilgi sistemi yöntemleriyle saptanması (Yüksek Lisans Tezi). Mersin Üniversitesi Fen Bilimleri Enstitüsü, Mersin, Türkiye. 